\title{
INCOME EXPECTATIONS, CREDIT TO HOUSEHOLDS, AND PROPERTY PRICES: EVIDENCE FROM INDONESIA AND BRAZIL
}

\author{
Huson Ali Ahmed \\ Department of Finance, Deakin Business School, Deakin University, Australia. \\ Email: huson.aliahmed@deakin.edu.au
}

\begin{abstract}
We investigate the long-term cointegration relation between residential property prices, household credit expansion, and household income expectations and identify the channels through which income expectation impacts residential property prices in the short term for Indonesia and Brazil. We find that improved income expectations raise the demand for credit, impacting residential property prices. Similar improvements in income expectations also serve as important indicators for credit policy decisions, making more funding available to the household sector against the backdrop of rising property prices. In the short run, property prices respond significantly to one-time shocks in income expectations in Indonesia, while credit to households responds positively to property prices and private consumption expenditures in Brazil.
\end{abstract}

Keywords: Income expectation; Household credit; Structural breaks; Shocks.

JEL Classifications: C5; E1.

Article history:

Received : July 21, 2019

Revised : November 20, 2019

Accepted : January 22, 2020

Available online : January 31, 2020

https://doi.org/10.21098/bemp.v23i0.1174 


\section{INTRODUCTION}

Considered the backbone of the financial sector, household credit could have a direct impact on the stability of the housing sector. Therefore, the continuous flow of funding into the household sector is vital to the development of the economy through the facilitation and promotion of financial intermediation to meet housing credit demands. Although the financial sector is regulated, its lending decisions are very dependent upon household expectations of future income and the collateral value of household assets. As housing prices rise, this adds more equity to household accounts, as well as collateral value for lenders. It is therefore in the interest of households and the financial sector to understand the dynamic interactions between income expectations, property prices, and credit to households. Previous studies document that credit cycles positively affect asset prices (Kiyotaki and Moore, 1997; Bernanke et al., 1999; Chen et al., 2007; Liabson and Mollerstrom, 2010; Foote, Girardi, and Willen, 2012; Wang and Zhang, 2014; Favara and Imbs, 2015; Adelino, Schoar, and Severino, 2017), while income expectations positively impact consumption expenditures and economic activities (Ludgivson, 2004; Davis and Zhu, 2009; Davis and Zhu, 2011). So far, to the best of our knowledge, no other studies have examined the interaction between income expectations, credit policy, and property prices in a dynamic setting, particularly for two vibrant emerging markets such as Indonesia and Brazil.

The motivation for the choice of Indonesia and Brazil as the units of analysis is the fact that Indonesia is one of the emerging economies with the great potential for housing and financial sector development. It is Southeast Asia's largest economy and it has a number of characteristics that put it in a great position for new advancement in economic development. As of 2020, Indonesia has a population of 274 million $^{1}$ and the country is ranked the 16th largest economy in the world, will ultimately join the economic powerhouses of China, Japan, and Korea. As the Indonesian economy grows the emergence of a growing middle-class population that can afford to buy and own property. This is the major driver of the real estate sector in Indonesia. Second, the country has a young population, with around 50\% below the age of 30 , with many Indonesian expected to buy their first property by the age of 40 . Similarly, Brazil, with a population of 212 millions as of $2020^{2}$, is one of the largest economies in South America and is currently ranked ninth in the world. The rise in its middle class will put significant pressure on housing demand and the credit sector, with strong potential for development of the housing and credit markets in the years to come.

In this paper, we examine how household income expectations explain financial institutions' credit policy decisions against the backdrop of rising property prices in the long run. We also examine the dynamic linkage between household income expectations, credit to households, and residential property prices. More importantly, we identify the channel(s) through which household income expectations impact residential property prices. Establishment of the linkages between income expectations, household credit, and property prices has major policy implications for both household consumption and investment decisions,

\footnotetext{
1 http://worldpopulationreview.com/countries/indonesia-population/

$2 \mathrm{http} / /$ /worldpopulationreview.com/countries/brazil-population/
} 
as well as financial institutions' credit policy decisions. We thus contribute to the literature on household credit cycles and property markets that studies the linkage between credit cycles and property price cycles, income expectations, and consumer spending.

We present two channels through which income expectations affect property prices: the credit channel and the wealth channel. The credit channel is based on the supply-side hypothesis, which is based on the willingness of financial institutions to supply funding to the household sector with a lower default probability for household borrowers. For example, Asea and Bloomberg (1998) demonstrate that banks change their lending standards systematically over a cycle. Favara and Imbs (2015), e.g., suggest that an exogenous expansion in mortgage credit has significant effects on house prices. Thus, the general consensus is that, given a positive economic outlook, banks relax their lending standards, but restrict them when the economy undergoes a downswing. Further, Mian and Sufi (2018) argue that the interaction between house prices and credit supply expansion has led to the question of whether the increase in house prices is the initial shock and the rise in household debt a response, as argued by Laibson and Mollerstrom (2010), Foote, Girardi, and Willen (2012), and Adelino, Schoar, and Severino (2017). Mian and Sufi (2018) further suggest that an "optimism" shock leads to a rise in house prices, where credit merely follows.

Alternatively, based on the demand-side hypothesis, household demand for credit arises with improvements in household income expectations. The subsequent rise in household wealth leads to greater demand for household credit for consumption items, including housing. The positive impact of housing demand led the residential property prices to rise. This is consistent with the permanent income hypothesis, which suggests that households plan their consumption and investment decisions based on long-term income, and short-term changes in income therefore do not influence consumption behavior.

Overall, the interaction between households' demand for credit and institutions' supply of credit will have a positive impact on housing demand, and hence house prices. Our hypothesis is therefore twofold. First, we propose that both income expectations and household sector credit drive residential prices in the long run. Second, we also propose the dynamic linkage between household income expectations, household credit, and property prices. According to the credit demand hypothesis, improved expectations will have a positive impact on property prices via the wealth channel, whereas, according to the credit supply hypothesis, improved income expectations exert a positive impact on property prices via the credit channel.

There are three approaches to testing these hypotheses. First, we ascertain the factors driving house prices in the long run. We consider five important factors that can directly and indirectly affect residential property prices. These include fundamental factors such as the amount of credit available to households, borrowing costs proxied by short-term interest rates, and household income expectations proxied by consumer sentiment about household financial and business conditions; macroeconomic factor, proxied by the gross domestic product to reflect aggregate demand; and a household factor proxied by household private consumption expenditures. We ascertain the unit root property of each series, 
using both a standard unit root test process and a unit root test with structural break(s) using the Narayan and Popp $(2010,2013)$ test. Second, we determine the long-run equilibrium relationship between residential property prices and the factors identified above, using dynamic ordinary least squares (DOLS). Third and the most importantly, to understand the dynamic interactions between household income expectations, household credit, and property prices. To achieve this, we first develop identification strategies by placing a contemporaneous restriction within a structural vector autoregressive (SVAR) framework and identify the initial shocks and feedbacks through impulse response functions (IRFs). As a robustness check, we also use an autoregressive distributed lag (ARDL) model that captures both short-run- and long-run properties to explain residential property prices.

The key findings show a cointegrating relationship between house prices and other factors in the model for both Indonesia and Brazil. From the cointegration equations, we can confirm that for Indonesia, in the long run, property prices are significantly and positively explained by income expectations and the economic performance and negatively affected by credit to households and private consumption expenditures. However, for the Brazilian economy, credit to households, private consumption expenditures, and income expectations positively affect property prices. Findings are in line with the literature (Green and Hendershott, 1996; Malpezzi, 1999; Capozza et al., 2002; Meen, 2002) that shows a cointegration relationship between house prices and fundamental factors. Our findings thus contribute to the literature on emerging housing and credit markets, which assumes the view that there are long-run relationships between property prices and income.

In terms of dynamic interactions between income expectations, household credit, and house prices, the estimates from SVAR suggest that property prices are a response to income expectations via the wealth channel for Indonesia. The shocks to income expectations, economic performance and private consumption expenditures affect household credit in Indonesia. This finding is consistent with that of Mian and Sufi (2018), who suggest that an optimism shock leads to an increase in house price, with credit merely follows the increase in house price. Similarly, house prices respond to both income expectations and economic performance. However, we find no significant evidence of household credit expansion in response to rises in property prices. For the Brazilian economy, shocks in income expectations have no impact on property prices, while property prices respond significantly to both economic performance and private consumption expenditures. Similarly, household credit responds sharply to rises in property prices. This finding is consistent with that of Favara and Imbs (2015), who suggest that an exogenous expansion in mortgage credit has significant effects on house prices.

The remainder of this paper is organized as follows. Sections II and III review the empirical and theoretical underpinnings of the relationship between household income expectations, credit to households, and residential property prices. Section IV describes our econometric methods and the data, variables, and model specifications. Section V discusses the results, and Section VI concludes the paper. 


\section{LITERATURE REVIEW}

The literature on household income expectations, credit expansion, and property prices can be categorized into three strands. The first strand of the literature focuses on understanding the fundamental factors driving property prices. Among others, Green and Hendershott (1996), Malpezzi (1999), Capozza et al. (2002), Meen (2002), Gallin (2006), Chen et al. (2007), and Wang and Zhang (2014) suggest a cointegration relationship between property prices and fundamentals factors such as income and interest rates. The second strand of literature focuses on the linkage between credit cycles and property price cycles (Davis, 1993; Herring and Wachter, 1999; Davis and Zhu, 2009; Davis and Zhu, 2011) and expectations and credit cycles (Fuster et al., 2010; Justiniano, Primiceri, and Tambolotti, 2015). For example, Davis (1993) suggests that lending to property and construction companies alone is one of the most procyclical and volatile elements of banking activities. Accordingly, changes in property prices will have major impacts on banks' asset quality and the value of bank capital, thus affecting banks' lending capacity (Davis and Zhu, 2009). Further, Davis and Zhu (2011) investigate the determinants of commercial property prices and their interaction with aggregate banks' lending. The authors have built an illustrative model that suggests that bank lending is closely related to property prices, and property markets can develop cycles, given plausible assumptions.

The third strand of literature focuses on the theoretical and empirical underpinnings of the interaction between credit expansion and asset prices (Kiyotaki and Moore, 1997; Bernanke et al., 1999; Liabson and Mollerstrom, 2010; Foote, Girardi, and Willen, 2012; Favara and Imbs, 2015; Adelino, Schoar, and Severino, 2017). For example, Favara and Imbs (2015) suggest that an exogenous expansion in mortgage credit has significant effects on house prices. They further suggest that house prices are well explained by the credit expansion induced by the banking sector's deregulation.

A feature of the literature cited above is that it focuses more on household credit and property prices, without emphasizing on how household income expectations affect property prices via different channels. Thus, this paper offers a new dimension to the literature and offers insight into the dynamic aspects of the interactions between house prices, income expectations, and credit supply expansion. We develop an identification strategy to answer the following questions: first, whether an increase in house prices is the initial shock and the rise in credit to households is a response to it; second, whether improved household income expectations are the initial shock and the rise in house prices is the response; and third, whether credit expansion is the initial shock and the rise in property prices is the response to it.

\section{THEORETICAL FRAMEWORK AND HYPOTHESIS DEVELOPMENT}

In this section, we present the theory underpinning the linkages between income expectations, household credit, and property prices and develop testable hypotheses. Based on Figure 1, we propose that household income expectations, as reflected in consumer confidence index affect residential prices through the wealth and credit channels. 
Figure 1.

This figure reports the transmission channels through which income expectation affects residential house prices.

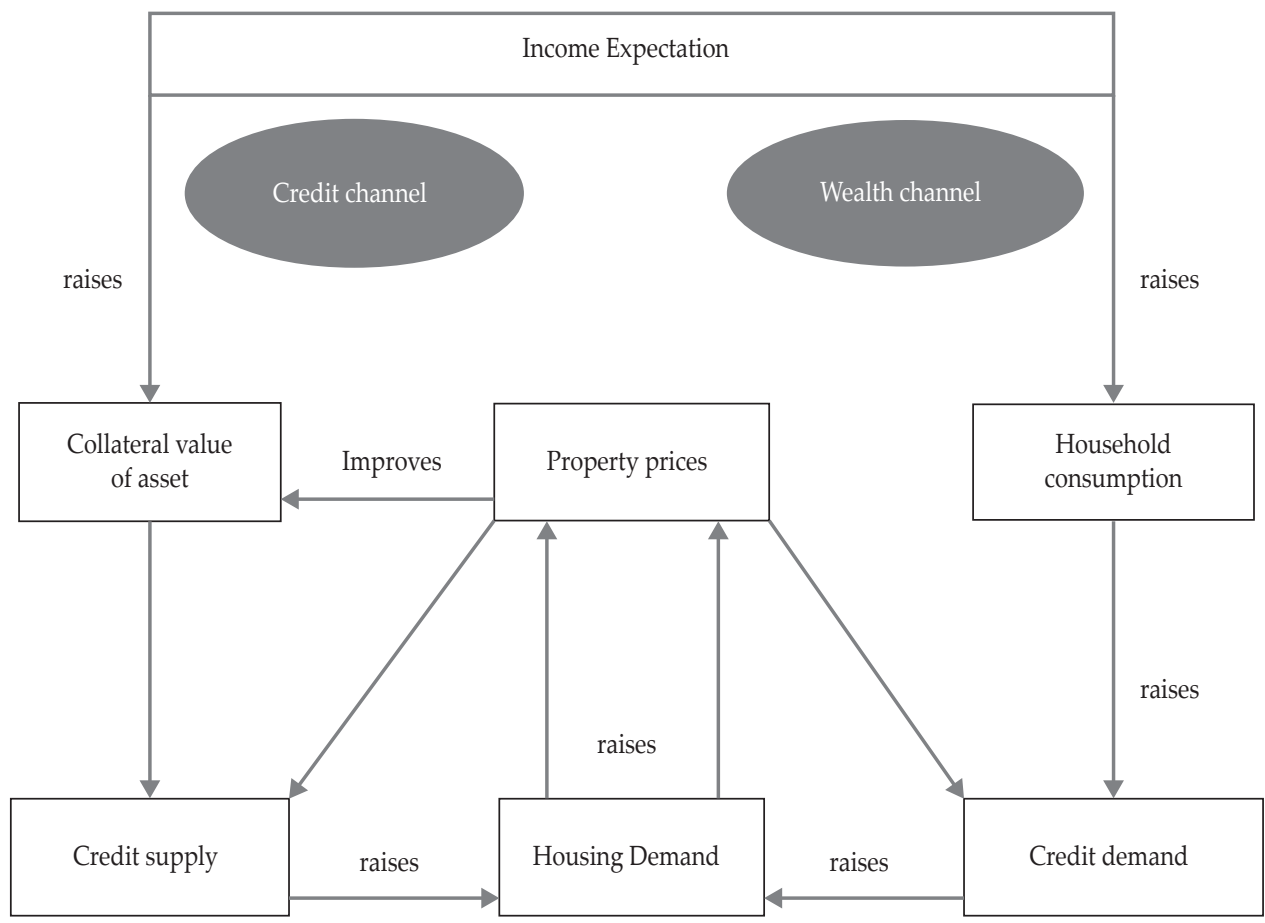

As shown in Figure 1, changes in property prices can be well explained by the microeconomic fundamentals of credit demand and credit supply. The theory of credit demand, the theory of credit supply, and property prices are well illustrated by Rajan (1994), Kiyotaki and Moore (1997), Bernanke et al. (1999), Liabson and Mollerstrom (2010), and Favara and Imbs (2015). Improvement in household income expectations increases household wealth, which then leads to greater demand for household credit and thus has a positive impact on residential property prices. This contention is consistent with the permanent income hypothesis, which suggests that households plan their consumption and investment decisions based on long-term income, and, therefore, short-term changes in income do not influence consumption behavior. According to the credit supply hypothesis, financial institutions consider positive household income expectations against the backdrop of increases in propriety prices an important lending decision criterion. The rise in property prices improves the quality of collateral for banks' lending. The lending institutions consider lowering lending standards as the default probability of borrowers decrease.

In the long run, the housing market is assumed to be in equilibrium, therefore, house prices, like the price of any financials or commodities, are determined by demand and supply factors (Gallin, 2006), ${ }^{3}$ credit expansion, and income

3 Similar specifications are detailed out by Gallin (2006), identifying both demand and supply shifters for house prices. 
expectations (Rajan, 1994; Kiyotaki and Moore, 1997; Bernanke et al., 1999; Ludvigson, 2004; Mollerstrom, 2010; Favara and Imbs, 2015). Therefore, in equilibrium, the house price is a function of credit demand shifters, credit supply shifters, and other exogenous factors. The following model describes the theoretical underpinnings of the relationship between property prices and the factors that drive property prices, which reflect the credit demand, credit supply, and other exogenous factors. Therefore, property prices can be modeled as

$$
P_{t}=\gamma_{0}+\gamma_{1} C D_{t}+\gamma_{2} C S_{t}+\gamma_{3} Z_{t}+\varepsilon_{t}
$$

where $P_{t}$ denotes the house price; $C D_{t}$ and $C S_{t}$ are credit demand and credit supply shifters. $Z_{t}$ represents other purely exogenous factors, such as GDP; and a monetary policy variable is proxied .by short-term interest rates, as demonstrated by Runstler and Vlekke (2018), who find large and long cycles between credit cycles and house prices. For example, Favara and Imbs (2015) suggest that an exogenous expansion in mortgage credit has significant effects on house prices.

The question of what constitutes both credit demand and credit supply shifters remains unanswered. House prices can be determined by both short- and long-run factors. Exogenous demand for drivers of residential property prices could include income expectations, household credit, interest rates, consumption patterns, and economic performance (Gallin, 2006). Any improvement in income expectations, consumption expenditures and economic performance will lead to greater demand for credit, thus positively impacting property prices. In contrast, any increase in user costs will lower the demand for credit, thus having a negative impact on property prices. From the supply side, any improvement in economic outlook or income expectations will encourage financial institutions to lower their lending standards, since such will lower non-performing loans and improve the collateral value of assets held by financial institutions. According to the credit supply hypothesis, financial institutions consider a positive economic outlook to be an important indicator for credit policy decisions. It allows the financial institutions to make more funding available to the household sector, hence, credit supply becomes cheaper and more abundant (Main and Sufi, 2018). Thus, given any positive shocks in income expectations, lending institutions respond positively to improved income expectations of households by supplying more credit or lowering lending standards to the household sector. We therefore propose the following hypothesis.

H1: Improved income expectations, as reflected in consumer confidence index, have a positive impact on property prices via both the credit and wealth channels.

In reciprocal terms, improvement in the collateral value of mortgage assets reduces the probability of banks losing money from expected lending. Therefore, banks are willing to extend new credit for housing purchases and new construction. A higher asset value can develop households' expectations for higher future income (based on future bank borrowing) and decrease the probability of default on bank loans, thus lowering bank standards for lending to households. We therefore empirically test the relationship between household income expectations and 
bank credit policies. More generally, through financial accelerator mechanism, bank credit to other sectors also increases if real estate is used as collateral. We thus propose the following hypothesis.

$\mathrm{H} 2$ : Household credit responds positively to a rise in property prices as improvements in the collateral value of assets lowers the probability of default, or financial institutions lower their lending standards given an expected rise in property prices.

\section{ECONOMETRIC METHODS AND DATA DESCRIPTION}

In this section, we describe the econometric methods and the data. We employ a number of econometric methods, including DOLS, the SVAR model, and ARDL model to understand the interactions between household income expectations, credit expansion, and property prices.

\section{A. Econometric Methods}

Based on our preceding discussions, to explore the long-run relationships between residential property prices and the factors that drive property prices, we use a DOLS model. For dynamic interactions between income expectations, household credit, and residential house prices, we develop an SVAR framework and identify the channels through which income expectations impact property prices.

\section{A1. Long-Run Model Using DOLS}

The DOLS approach is attributed to Saikkonen (1991) and Stock and Watson (1993). It is a simple approach for developing an asymptotically efficient estimator that eliminates feedback in a cointegrating system. Thus, it is an augmented approach to the cointegrating regression with the lags and leads of both dependent and independent variables, so that the resulting cointegrating equation error term is orthogonal to the entire history of stochastic regressor innovations. Our empirical model is based on the work of Stock and Watson (1993) and Masih and Masih (1996). The modeling of property prices and variables related to property prices are often associated with the problem of endogeneity and simultaneity biases. The use of DOLS partly alleviates these issues, since the model considers the lead and lag of both dependent variables, which conditionally serve as instruments to minimize endogeneity bias. The functional form of the long-run model is

$$
\begin{aligned}
\text { PP_RES }_{t} & =\propto_{0}+\propto_{1} G D P_{t}+\propto_{2} \text { CRHH }_{t}+\propto_{3} \text { PVCEXPD }_{t}+\propto_{4} C C I_{t} \\
& +\propto_{4} \text { STINTR }_{t}+\epsilon_{t}
\end{aligned}
$$

where $P P_{-}$RES is the residential property price index, GDP is the measure of economic performance at a constant price with 2010 as the base year, $C R H H$ is the credit to households in Indonesia and Brazil (in billions of US dollars), PVCEXPD is private consumption expenditures (in billions of US dollars), CCI is the consumer confidence index to proxy for households' income expectations, and STINTR is 
Short-Term Interest rate. All the variables are in their natural logarithmic form, except the interest rate. DOLS corrects for possible bias among the regressors and is therefore preferable to other single-equation cointegration techniques, such as Engle and Granger's (1987) two-step estimator. The model also produces estimates that are asymptotically normally distributed and therefore more suitable for making direct statistical inferences on the parameters of the cointegrating vector. Most importantly, DOLS can accommodate different orders of integration, i.e., it allows for the direct estimation of a mixture of I (0) and I (1) variables, and DOLS is asymptotically equivalent to the full information maximum likelihood approach developed by Johansen (1988).

\section{A2. The SVAR Framework}

To understand the dynamic interactions between income expectations, household credits, and property prices, we adopt and design am SVAR framework based on the work of Kim and Rubini (2000) and Elbourne (2008), who examines the linkage between the UK housing market and monetary policy transmission using an SVAR framework.

An SVAR has the general form

$$
A_{0} X_{t}=A_{1}(L) X_{t}+B_{\varepsilon t}
$$

where $X_{t}$ represents an $n$-vector of relevant variables,

$$
X_{t}=\left[\Delta G D P_{t}, \Delta P V C E X P D_{t}, \Delta C R H H_{t}, \Delta S T I N T R_{t}, \Delta P P_{-} R E S_{t}\right]
$$

and $A_{0}$ and $B$ are $6 \times 6$ matrixes of coefficients, with $A_{1}(L)=\sum_{i=1}^{q} A_{1} L_{i}$ representing the matrix polynomials in the lag operator and $A_{1 i}$ a $6 \times 6$ matrix of coefficients. The matrix $A$ is used to define the impulse responses of endogenous variables to structural shocks, denoted by

$$
\varepsilon_{t}=\varepsilon_{t}^{G D P}, \varepsilon_{t}^{P V C E X P}, \varepsilon_{t}^{C R H H}, \varepsilon_{t}^{\text {STINTR }}, \varepsilon_{t}^{P P_{-} R E S}
$$

Matrix $B$ contains the model's structural form parameter, and $\varepsilon_{t}$ is an $n$-vector of serially uncorrelated zero-mean structural shocks with identity covariance matrix $\sum_{\varepsilon}=E\left[\varepsilon_{t} \varepsilon_{t}^{\prime}\right]=I$.

The reduced form of the vector autoregressive model can be represented as

$$
X_{t}=C(L) X_{t}+u_{t}
$$

where

$$
\mathrm{C}(L) X_{t}=A_{0}^{-1}, A_{1}(L)
$$


with

$\mathrm{A}_{0} u_{t}=\mathrm{B} \varepsilon_{t}$

The residuals $u_{\mathrm{t}}$ in the reduced model are also presumed to be white noise, but they could be correlated with each other, due to the contemporaneous effect of variables across equations. We estimate the $A B$ model proposed by Amisano and Giannini (1997).

\section{A3. Identification and Contemporaneous Restriction}

The interaction between house prices and credit supply expansion has led to the question of whether an increase in house prices is the initial shock and credit expansion is a response to it. For example, an optimism shock could have led to a rise in house prices, with credit merely following the rise in house prices, as suggested in Main and Sufi (2018). The empirical evidence on whether house prices are more likely to be a response to credit supply expansion rather than a cause is unclear. Exogenous changes in credit supply have quantitatively large effects on house prices (e.g., Adelino, Schoar, and Severino, 2015; Favara and Imbs, 2015; Di Maggio and Kermani, 2017; Mian, Sufi, and Verner, 2017).

\section{A4. Contemporaneous Restriction}

The restrictions imposed on the SVAR system are mainly derived from economic explanations of the contemporaneous effects among the variables. Restrictions on contemporaneous relations between the variables in the SVAR system are given below.

$$
\begin{aligned}
& {\left[\begin{array}{c}
u_{G D P} \\
u_{C C I} \\
u_{P V C E X D} \\
u_{C R H H} \\
u_{S T I N T R} \\
u_{P P \_R E S}
\end{array}\right]\left[\begin{array}{cccccc}
1 & 0 & * & 0 & 0 & 0 \\
* & 1 & 0 & 0 & 0 & 0 \\
* & * & 1 & 0 & 0 & 0 \\
* & * & 0 & 1 & 0 & * \\
* & 0 & 0 & * & 1 & 0 \\
* & * & 0 & * & * & 1
\end{array}\right]=\left[\begin{array}{llllll}
* & 0 & 0 & 0 & 0 & 0 \\
0 & * & 0 & 0 & 0 & 0 \\
0 & 0 & * & 0 & 0 & 0 \\
0 & 0 & 0 & * & 0 & 0 \\
0 & 0 & 0 & 0 & * & 0 \\
0 & 0 & 0 & 0 & 0 & *
\end{array}\right]\left[\begin{array}{c}
\varepsilon_{G D P} \\
\varepsilon_{C C I} \\
\varepsilon_{P V C E X D} \\
\varepsilon_{C R H H} \\
\varepsilon_{S T I N T R} \\
\varepsilon_{P P \_R E S}
\end{array}\right]} \\
& \mathrm{A}_{0} u_{t}=\mathrm{B} \varepsilon_{t}
\end{aligned}
$$

Note that we select an optimum lag-length of two, based on Schwarz selection criteria (SIC). The variables on the left-hand side of this SVAR system are the residuals ( $u$ values) obtained from the reduced-form vector autoregressive. On the right-hand side, the six structural innovations ( $\varepsilon$ values) represent shocks to the GDP, income expectations, private consumption expenditures, credit to households, the short-term interest rate, and the real residential proper price index, respectively. In the above system of equations, we use * to denote the coefficients to be estimated. 
The short-term interest rate is used as a leading indicator for monetary policy shock. The first row in the SVAR system depicts a contemporaneous economic performance responses consumer confidence index. The second row in the SVAR system represents income expectations as reflected in consumer confidence index about changes in economic conditions, household and business financial conditions. If the economy performs well, it will have a positive impact on consumer confidence and income expectations. This confidence also increases as household wealth improves through housing equity. Thus, confidence levels can be contemporaneously affected by both economic performance and changes in property prices. We allow economic performance shocks to contemporaneously affect income expectations. The third row of the SVAR system represents private consumption expenditures, which is contemporaneously affected by both aggregate demand proxied by GDP and income expectations. We expect a positive demand shock generated from economic performance and improved optimism about household income expectations. The improved optimism will encourage households to consume more in the contemporaneous period. The fourth row of the SVAR system represents credit to households, which is contemporaneously affected by both GDP and income expectations. We expect a positive demand shock triggered by economic performance and a subsequent supply of credit to households to meet the demand for consumption items, including cars, housing, appliances, and investment goods. Further, credit to households is also contemporaneously affected by changes in property prices. The fifth row of the SVAR system presents monetary policy shocks proxied by short term interest rates which is assumed to be contemporaneously affected by both private consumption expenditure and aggregate economic performance. The sixth row in the SVAR system depicts the contemporaneous response of residential property prices to shocks emanating from income expectations, as reflected in CCI, economic performance, monetary policy shocks, and private consumption expenditures in the same period. Based on the permanent income hypothesis, a positive relationship is perceived between income expectations and personal consumption expenditures, as well as property prices, through the wealth channel. According to the credit supply hypothesis, financial institutions lower lending standards as there is a perceived improvement in household income expectations. For example, Favara and Imbs (2015) suggest that an exogenous expansion in mortgage credit has significant effects on house prices.

\section{A5. Impulse Response Functions}

We derive and use IRFs to examine the dynamic responses of the variables (GDP, CCI, PVCEXPD, CRHH, STINTR, and PP_RES) to various shocks within the SVAR system. Having identified the structural shocks, we can then find the impulse response of variables to a one-time shock to any variable in the model, which can be obtained from

$$
\begin{aligned}
& X_{t}=C *(L) \varepsilon_{t} \\
& C *(L)=C(L) A_{0}^{-1}
\end{aligned}
$$


to generate the IRF of $X_{t}$ to structural shocks to $\varepsilon_{t^{\prime}}$ where $A_{0}$ is a lower triangular matrix with ones on its main diagonal, that is, the structural IRF.

\section{B2. Data Definition and Sources}

To examine the linkage between household income expectations, credit to the household sector, and property prices, we estimate Equation (2) for property prices $\left(P P \_R E S\right)$, the dependent variable, along with household income expectations, proxied by CCI, STINTR, and GDP at a constant price' from quarter one, 2001 through quarter four, 2018. PP_RES is proxied by a real residential property price index, available and obtained quarterly from Banks for International Settlement. The short-term interest rate is the indicator rate for the Organization for Economic Co-operation and Development (OECD), normalized for the short term, respectively, for Indonesia and Brazil, extracted from Federal Reserve Economic Data (FRED). The quarterly data on credit to the household sector and private consumption expenditures for Indonesia and Brazil are obtained from FRED, in billions of US dollars. We use the CCI to proxy for household income expectations, extracted from the OECD Library database. The CCI is based on five questions that reflect both current and future household financial and business conditions, to proxy for income expectations. The construction of the CCI is exactly the same as for the Michigan Consumer Sentiment Index and is based on the following questions:

- Expected family finances in the next 12 months

- Expected economic conditions in the next 12 months

- Expected economic conditions in the next five years

- Whether it is a good or bad time to buy major household items

We use the quarterly index CCI to tally with other variables that are mostly quarterly. A CCI value of 100 indicates average optimism, whereas a value greater than 100 indicates that optimism outweighs pessimism, and vice versa.

\section{RESULTS AND DISCUSSION}

We designed the analyses in three steps. First, to find long-term cointegration relations between property prices and their determining factors, we follow the literature and employ the popular augmented Dickey-Fuller (ADF) test to draw possible inferences and ascertain the stationarity of each variable. We also consider unit root tests with structural breaks, based on a Dickey-Fuller (DF) test to ascertain the unit root properties of each series.

\section{A1. Unit Root Tests}

We use both standard ADF tests and ADF tests with structural breaks to determine the order of integration to examine the long-run relationship between $P P \_R E S$ and their determinants, namely, CCI, CRHH, GDP, STINTR, and PVCEXPD. The results are reported in Table 1, Table 2, Figure 2 and Figure 3, respectively.

For Indonesia, the standard ADF test results suggest that the null hypothesis of a unit root is not rejected at the $5 \%$ significance level for all variables except 
STINTR. This finding implies that the levels of all the variables, except STINTR, are nonstationary, but that their first differences are stationary. For Brazil, however, the ADF test results suggest that all the variables except CCI are I (I).

Table 1.

\section{ADF Unit Root Test}

In this table, we report the augmented Dickey-Fuller (ADF) unit root test results for all variables at both the level and first difference forms for Indonesia and Brazil. The null hypothesis of "unit root," is tested with the reported $t$-test statistics. We use Schwartz Information Criterion with auto lag selection, starting with a maximum of 10 lags. The $p$-value is in parenthesis. Finally, ${ }^{* * *}$ and ${ }^{* *}$ denote statistical significance at $1 \%$ and $5 \%$ level, respectively.

\begin{tabular}{lcccc}
\hline & \multicolumn{2}{c}{ Indonesia } & \multicolumn{2}{c}{ Brazil } \\
\hline Variable & Level & 1st difference & Level & 1st difference \\
\hline GDP & -2.325 & $-8.759^{* * *}$ & -0.640 & $-5.776^{* * *}$ \\
CRHH & $(0.447)$ & $(0.000)$ & $(0.973)$ & $(0.000)$ \\
& -1.618 & $-7.559^{* * *}$ & -.503 & $-7.368^{* * *}$ \\
CCI & $(0.775)$ & $(0.000)$ & $(.981)$ & $(0.000)$ \\
& -2.050 & $-8.819^{* * *}$ & -3.0184 & $\mathrm{~N} / \mathrm{A}$ \\
PVCEXPD & $(0.265)$ & $(0.000)$ & $(0.018)$ & \\
& -1.506 & $-9.936^{* * *}$ & -1.405 & $-2.181^{* * *}$ \\
PP_RES & $(0.822)$ & $(0.000)$ & $(0.574)$ & $(.006)$ \\
& -0.980 & $-7.691^{* * *}$ & -2.408 & $-2.964^{* *}$ \\
STINTR & $(0.755)$ & $(0.000)$ & $(.143)$ & $(0.043)$ \\
& $-3.700^{* * *}$ & $\mathrm{~N} / \mathrm{A}$ & -2.268 & $-4.441^{* * *}$ \\
& $(0.005)$ & & $(-0.444)$ & $(.003)$ \\
\hline
\end{tabular}

\section{A2. Unit Root Tests with Structural Breaks}

Figure 2.

\section{Structural Break Identification using DF autoregressive coefficient (Indonesia)}

This figure represents the time-break (TB) for respective variables for Indonesia. The graph identifies approximate break-date. The vertical axis presents autoregressive response coefficient over the period.

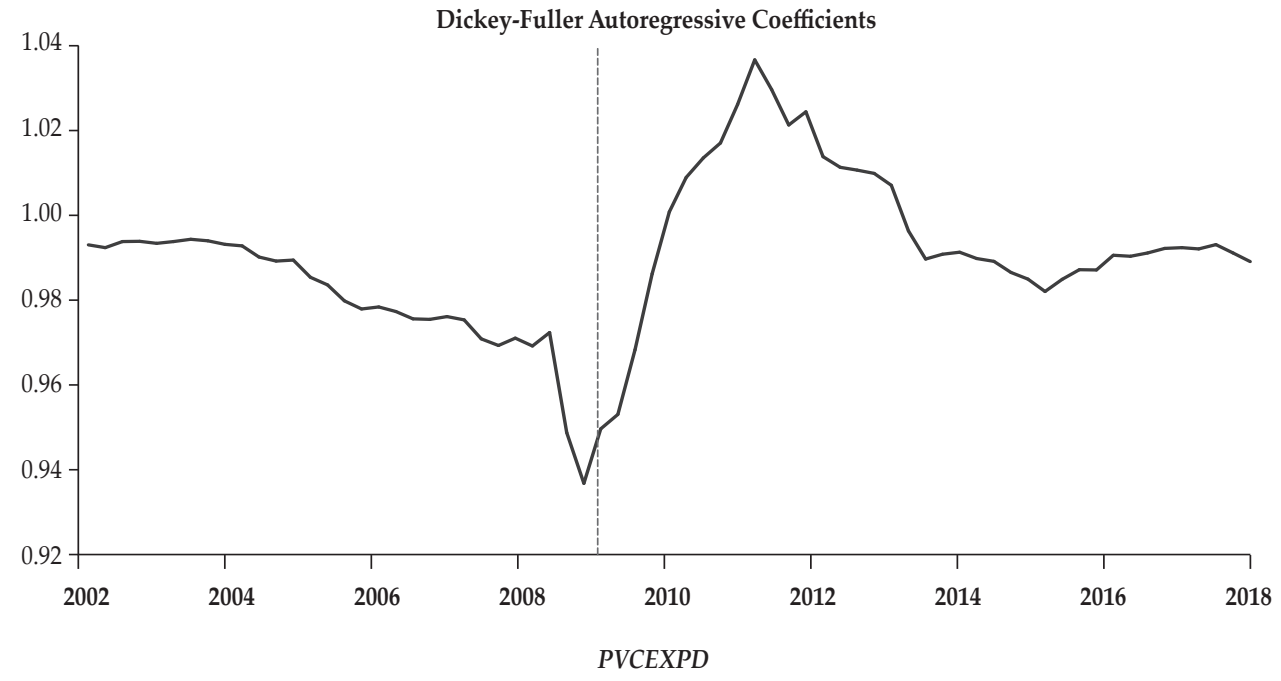


Figure 2.

Structural Break Identification using DF autoregressive coefficient (Indonesia) (Continued)
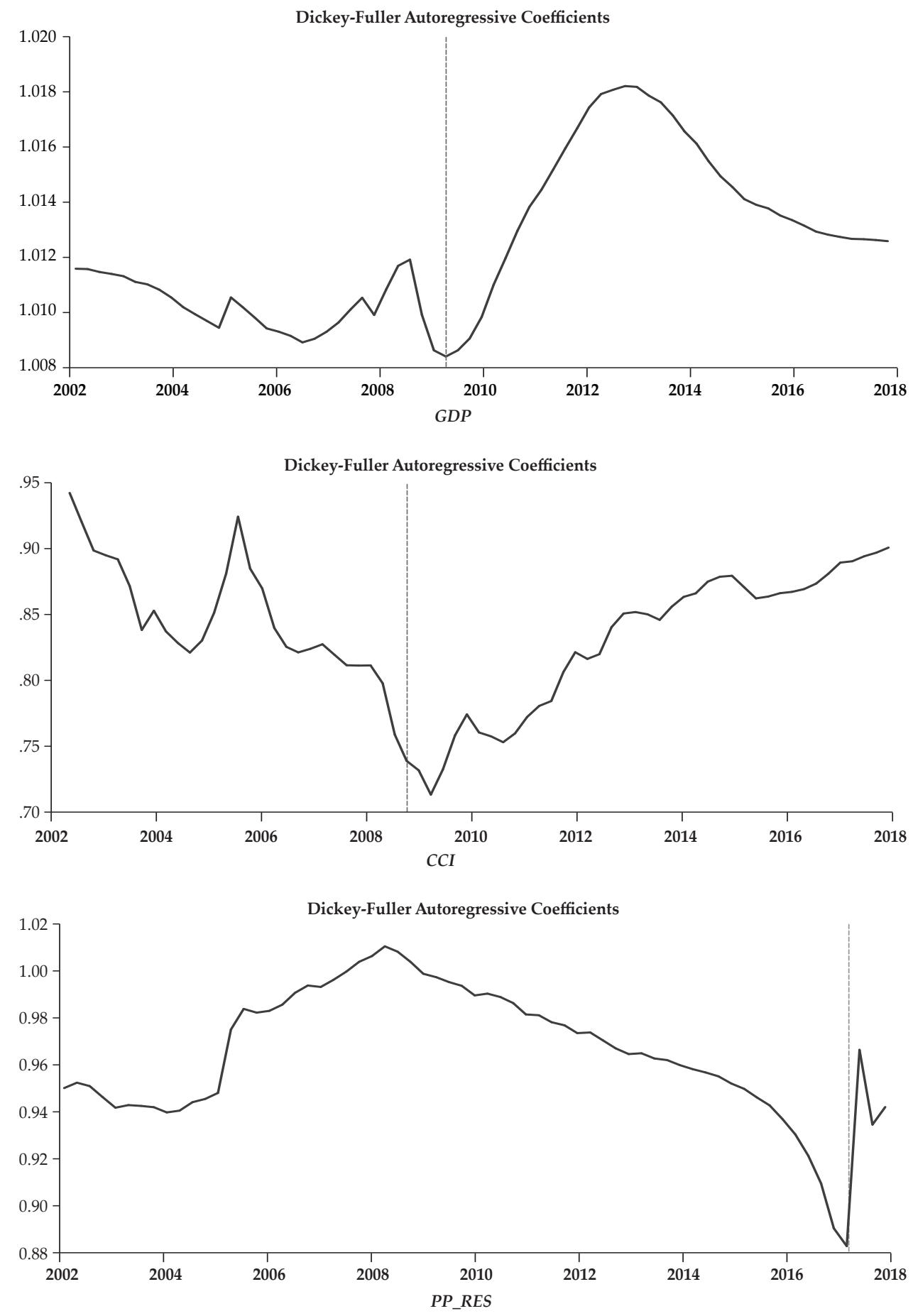
Figure 2.

Structural Break Identification using DF autoregressive coefficient (Indonesia) (Continued)
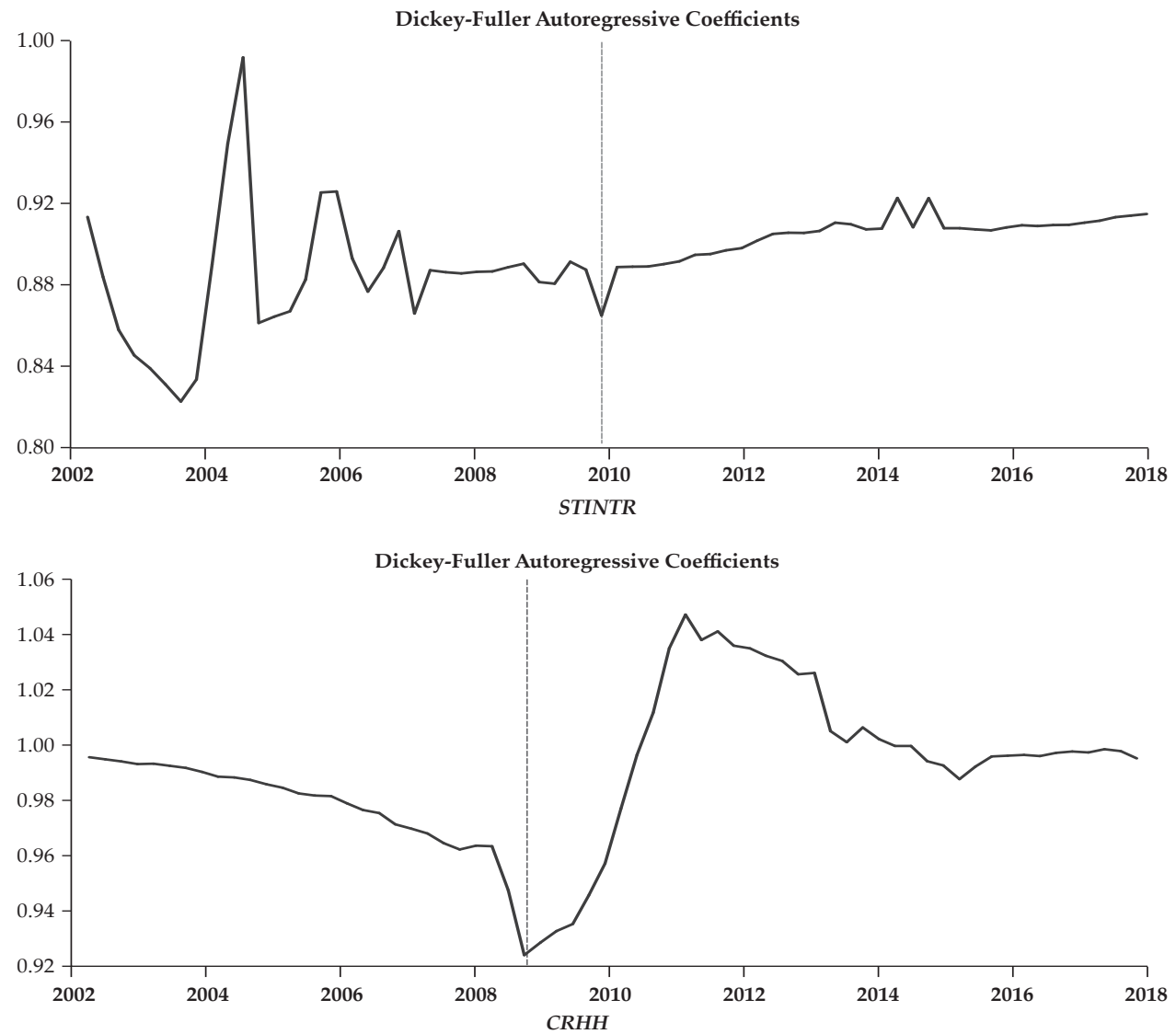

Figure 3.

\section{Structural Break Identification using DF Autoregressive Coefficient (Brazil)}

This figure represents the time-break (TB) for respective variables for Brazil. The graph identifies approximate breakdate. The vertical axis presents autoregressive response coefficient over the period.

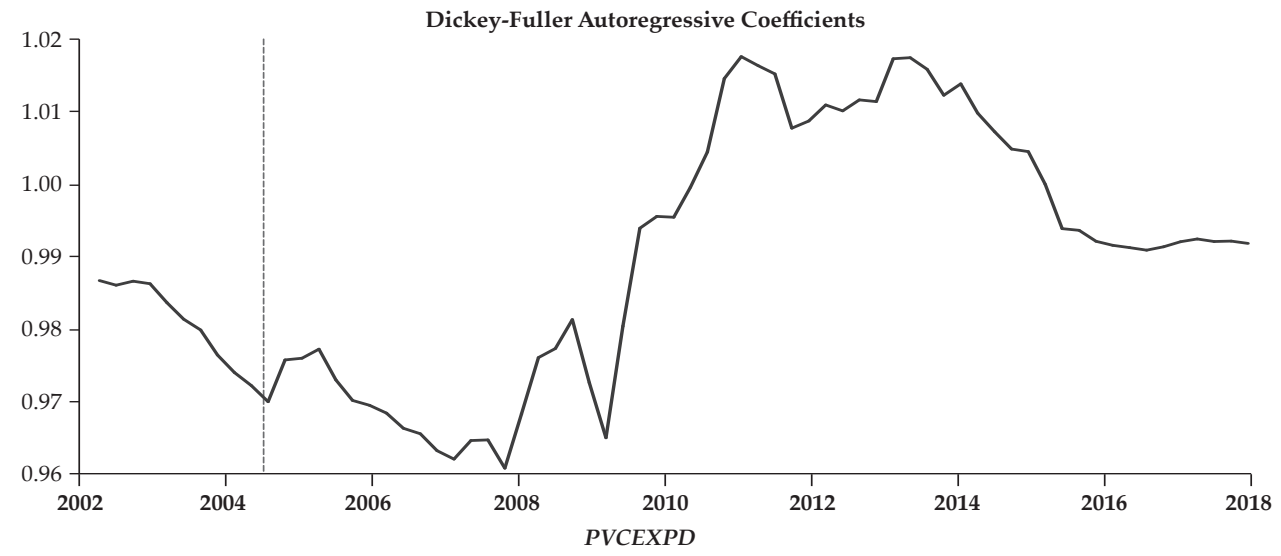


Figure 3.

Structural Break Identification using DF Autoregressive Coefficient (Brazil) (Continued)
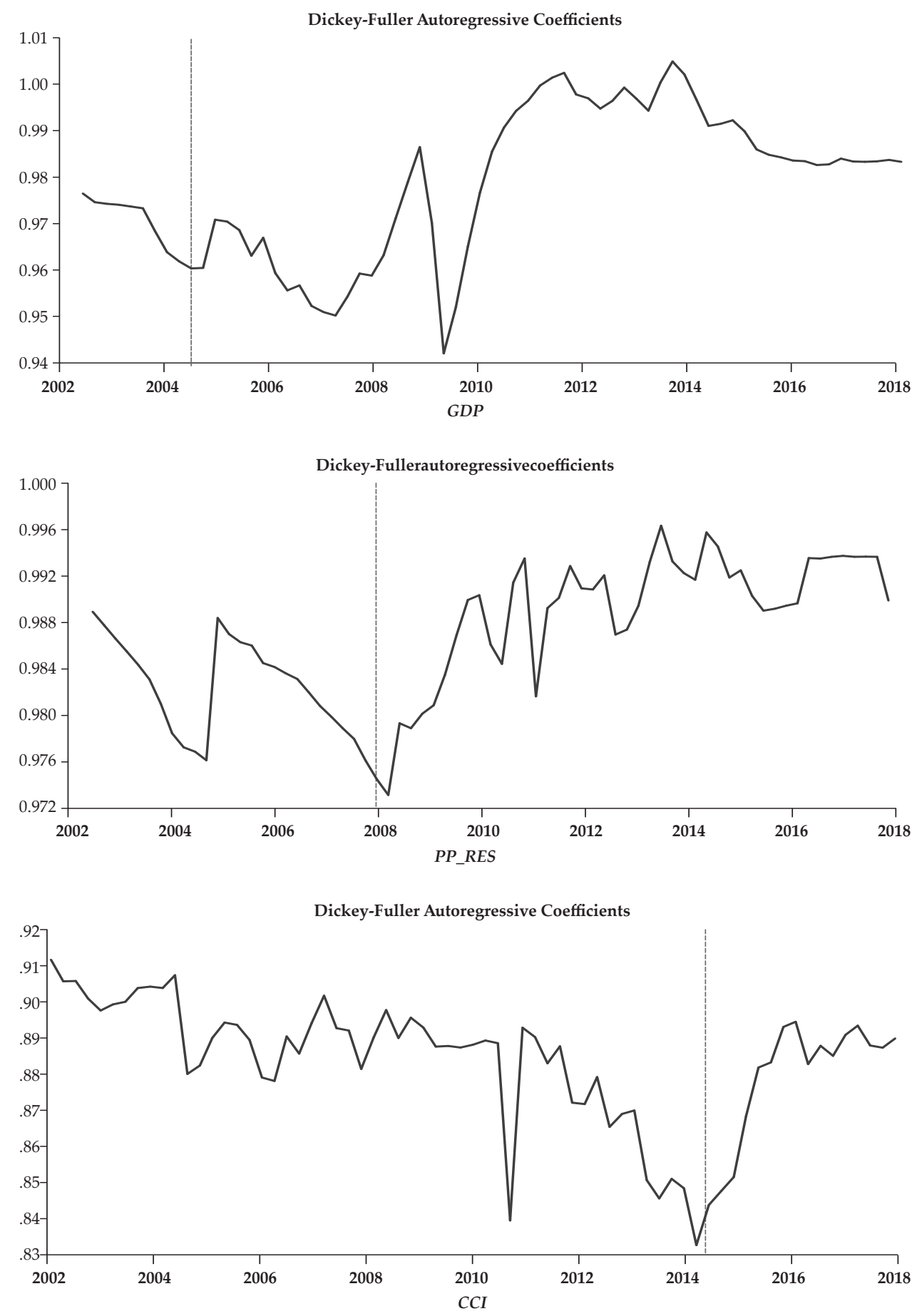
Figure 3.

Structural Break Identification using DF Autoregressive Coefficient (Brazil) (Continued)

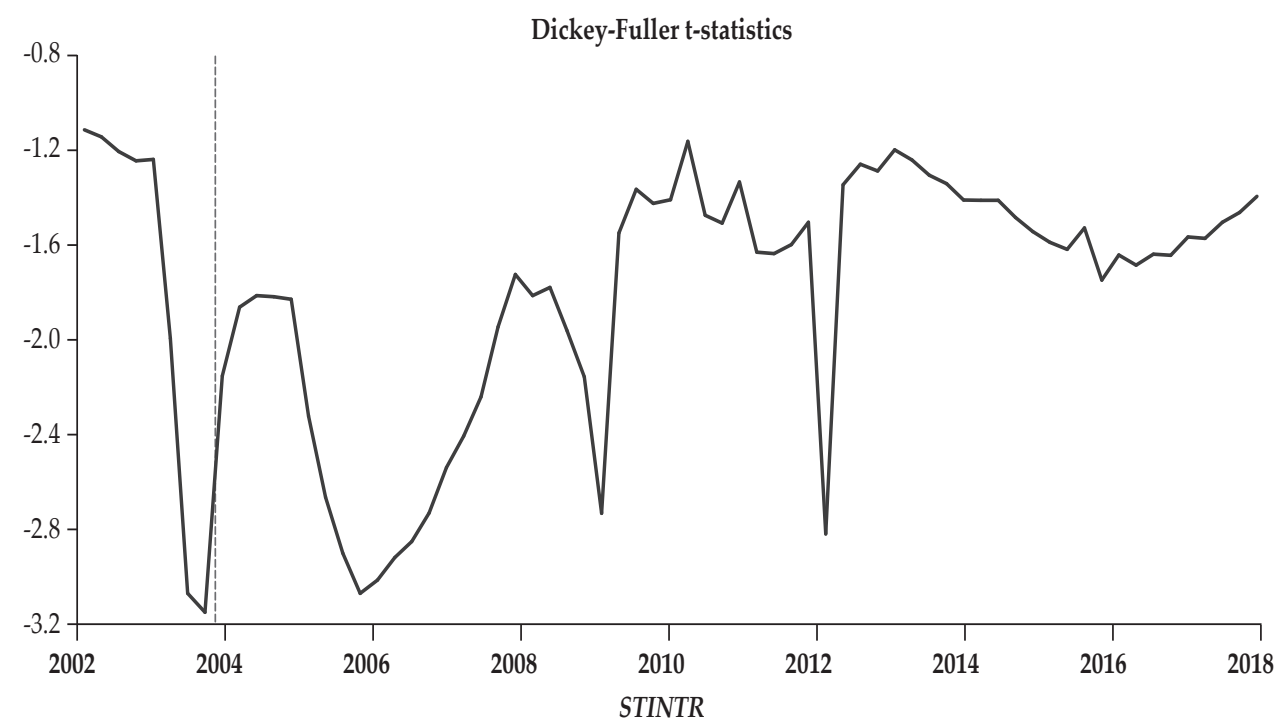

Dickey-Fuller autoregressive coefficients

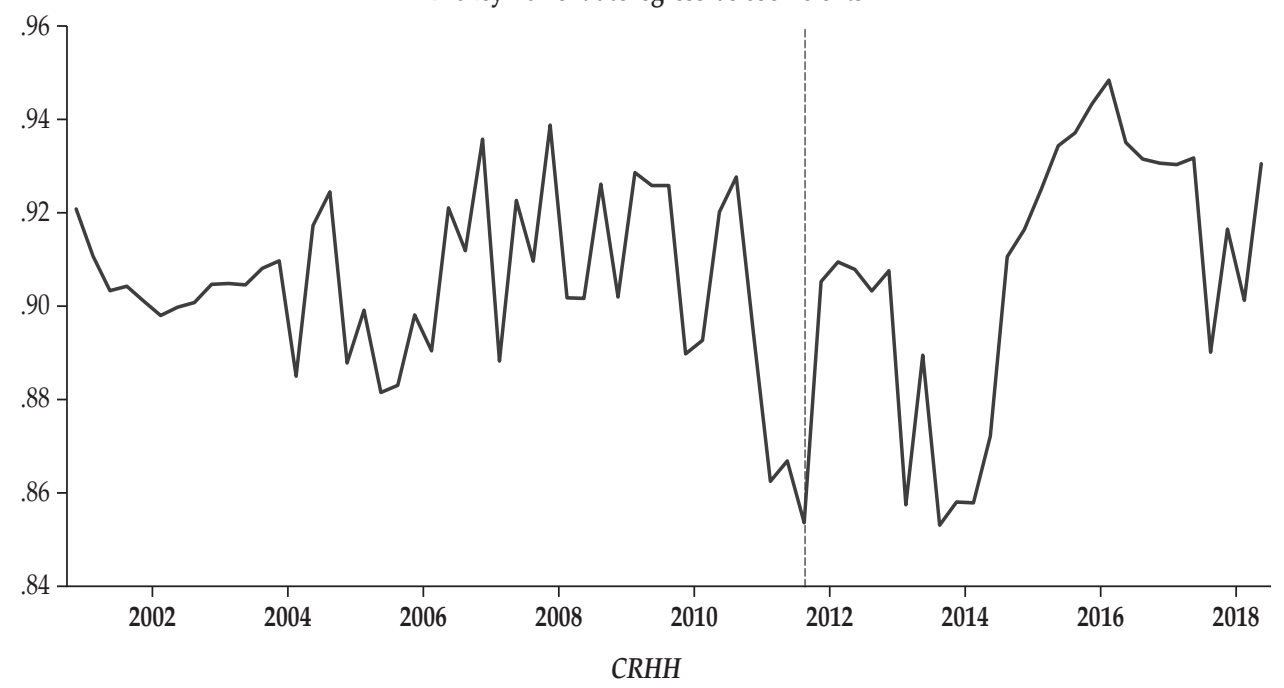


Table 2.

\section{ADF Unit Root Test with Structural Break for Indonesia and Brazil}

In Panel B, we report the ADF structural break unit root test results. We use a single break as identified based on Dickey-Fuller autoregressive coefficients. Finally, ${ }^{* * *}$ denotes statistical significance at $1 \%$ level. We use SIC criteria to determine the number of lag(s) allowing a maximum of 10 lags.

\begin{tabular}{lcccccc}
\hline \multicolumn{3}{c}{ Indonesia } & \multicolumn{3}{c}{ Brazil } \\
\hline Variable & \multirow{2}{*}{ TB } & Level & $\begin{array}{c}\mathbf{1}^{\text {st }} \\
\text { difference }\end{array}$ & \multirow{2}{*}{ TB } & Level & \multirow{2}{*}{$\mathbf{1}^{\text {st }}$ difference } \\
\hline GDP & \multirow{2}{*}{$2009 \mathrm{Q} 2$} & -5.057 & $-5.277^{* * *}$ & $2003 \mathrm{Q} 4$ & -2.110 & $-5.380^{* * *}$ \\
& & $p<0.5$ & $p<.01$ & & $p>0.5$ & $p<0.01$ \\
CRTHH & \multirow{2}{*}{$2009 \mathrm{Q} 1$} & -2.471 & $-7.757^{* * *}$ & $2011 \mathrm{Q} 4$ & -2.237 & $-8.098^{* * *}$ \\
& & $p<.5$ & $p<0.01$ & & $p>0.5$ & $p<0.01$ \\
CCI & \multirow{2}{*}{$2008 \mathrm{Q} 3$} & -2.196 & $-8.757^{* * *}$ & $2014 \mathrm{Q} 3$ & -1.790 & $-6.211^{* * *}$ \\
& & $p>.10$ & $p<.01$ & & $p>0.5$ & $p<0.01)$ \\
PVCEXP & \multirow{2}{*}{$2008 \mathrm{Q} 4$} & -1.432 & $-6.184^{* * *}$ & $2004 \mathrm{Q} 1$ & -2.136 & $-5.365^{* * *}$ \\
& & $p>.5$ & $p<.01$ & & $p>0.5$ & $p<0.01$ \\
PP_RES & \multirow{2}{*}{$2017 \mathrm{Q} 4$} & -1.581 & $-8.783^{* * *}$ & $2007 \mathrm{Q} 4$ & -3.928 & $-7.468^{* * *}$ \\
& & $p>.10$ & $p<.01$ & & $p>0.10$ & $p<0.01$ \\
STINTR & \multirow{2}{*}{$2009 \mathrm{Q} 4$} & $-4.672^{* * *}$ & $\mathrm{NA}$ & $2003 \mathrm{Q} 2$ & -3.131 & $-6.645^{* * *}$ \\
& & $\mathrm{p}<.01$ & & & $p>0.5$ & $p<.01$ \\
\hline
\end{tabular}

Next, we examine the presence of unit roots in all the variables, incorporating structural breaks for both Indonesia and Brazil. The break dates are identified using DF autoregressive coefficients. The results are depicted in Figure 2 and Figure 3 and Table 2. Overall, our results imply that two significant structural breaks characterize our data series. The two significant break dates for both countries are 2008 and 2009, with also 2017 for Indonesia. This structural characterization is evidence of the global financial crisis, which ravaged global economies. After sharp growth from the end of 2012 and throughout 2013, the property market slowed down. Average price increases slipped from 14\% in 2013 to around 3\% in 2017 and 2018. ${ }^{4}$ Therefore, possible reasons for such slow down were political uncertainty, lower occupancy rates, the introduction of a new luxury property tax, and a drop in the GDP per capita. We find Brazilian data to have some interesting features in terms of the housing market, monetary policy, and household consumption behavior. Overall, the unit root test with structural breaks appears to confirm the order of integration reported in Table 1.

\section{A3. Determination of Property Prices in the Long-run: DOLS estimates}

To understand the long cointegration relation between residential property prices and the factors driving these prices, we only consider DOLS. The DOLS model is estimated as specified in Equation (1). The results are reported in Table 3. The long-run coefficient estimates depict the nature of the cointegration relationship between property prices and GDP, CRHH, PVCEXPD, CCI, and STINTR for Indonesia and Brazil. The estimates confirm the long-run elasticity of property

\footnotetext{
4 See https://fred.stlouisfed.org/series/QIDR628BIS.
} 
prices to a $1 \%$ change in GDP, CRHH, PVCEXPD, and CCI. The long-run elasticity of property prices to income expectations as proxied by $C C I$ is the highest, followed by GDP, are statistically significant for Indonesia. This result is consistent with the permanent income hypothesis, according to which households plan for consumption and demand for credit based on long-term rather than short-term income. Surprisingly we observe a negative long-term relationship between property prices and credit to the household sector, as discussed in the preceding, which indicates that funding the household sector increases the supply of new houses mostly through housing construction, shifting the supply curve for houses in Indonesia to the right, resulting in a possible price decline. However, this relation is not statistically significant.

For Brazil, we find evidence of a long-term impact of income expectations, credit to households, and private consumptions expenditures on property prices. As opposed to an earlier conjecture, these two countries' economies could have structural differences; thus, the elasticity values of property prices to changes in income expectations CCI, GDP, CRHH and PVCEXPD are different. In Brazil, the theory of credit supply seems to be in line with the permanent income hypothesis. In other words, in the long run, the elasticity of property prices to income expectations, household consumption expenditures, and credit to households is positive, but negative in terms of GDP.

Table 3.

\section{Estimates of Long-run Coefficients from Cointegrating Regressions (DOLS)}

In this table, we report results for the long-run relationship between residential property price and other independent variables for which we find evidence of cointegration relations. The models are based on the HAC standard error \& covariance (Bartlett kernel, Newey-West fixed bandwidth). Given that the data frequency is quarterly, we use 1 lead and 1 lag for the estimation. The variables are PP_RES = Real Property Index, $C R H H=$ Credit to Household sector and other sectors serving household; $P V C E X P D=$ private consumption expenditure in USD; and CCI=is consumer confidence index. All variables are in natural logarithms except STINTR. Finally, ${ }^{* * *},{ }^{* *}$, and ${ }^{*}$ denote statistical significance at the $1 \%, 5 \%$, and $10 \%$ levels, respectively.

\begin{tabular}{lcc}
\hline Variables & Indonesia & Brazil \\
\hline GDP & $2.153^{* * *}$ & $-3.477^{* * *}$ \\
& $(0.171)$ & $(0.546)$ \\
CRHH & -0.004 & $0.104^{* *}$ \\
& $(0.000)$ & $(0.051)$ \\
PVCEXPD & $-1.074^{* * *}$ & $2.758^{* * *}$ \\
& $(0.061)$ & $(0.313)$ \\
CCI & $2.212^{* * *}$ & $0.387^{* * *}$ \\
& $(0.056)$ & $(0.151)$ \\
STINTR & 0.002 & -0.007 \\
& $(0.002)$ & $(0.005)$ \\
C & $2.0123^{* * *}$ & 0.556 \\
& $(0.162)$ & $(16.766)$ \\
Adj-R square & 0.970 & 0.984 \\
\hline
\end{tabular}


A4. Interactions between Income Expectations, Household Credit, and Property Prices The long-term cointegration relationship does not indicate the direction or feedback effects. Therefore to shed light on whether credit follows improved income expectations, with rising property prices in response to income expectations, we investigate the dynamic relation between household income expectations, credit to households, and residential property prices within the SVAR framework. The variables in the SVAR are all stationary in their first difference form, except for the interest rates. The optimum lag length is determined using Schwarz information criterion (SIC), with a length of two lags for both Indonesia and Brazil. The selected IRFs are reported in both Figure 4 and Figure 5, respectively, for Indonesia and Brazil. Our objective here is to understand the short-run dynamics of property prices in response to both the credit supply and the credit demand, rather than their response coefficients.

Figure 4 .

\section{Impulse Response Functions: Indonesia}

This figure represents the IRFs derived from the SVAR model (Model 1) for Indonesia. The impulse response function traces the effect of a one standard deviation shock to one of the variables on both current and future values of all the endogenous variables in the VAR system. Dashed lines represent the intervals of two standard deviations, while the solid lines represent the impulse function.

Accumulated Response to Structural VAR Innovations \pm 2 S.E.

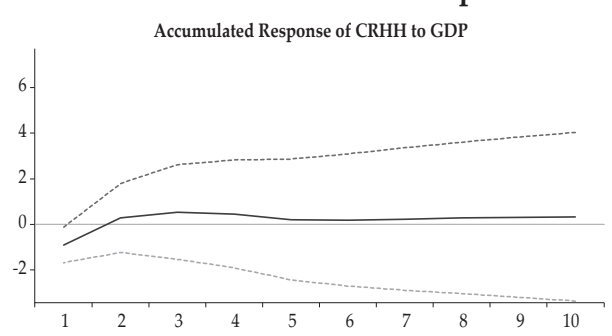

Accumulated Response of CRHH to CCI
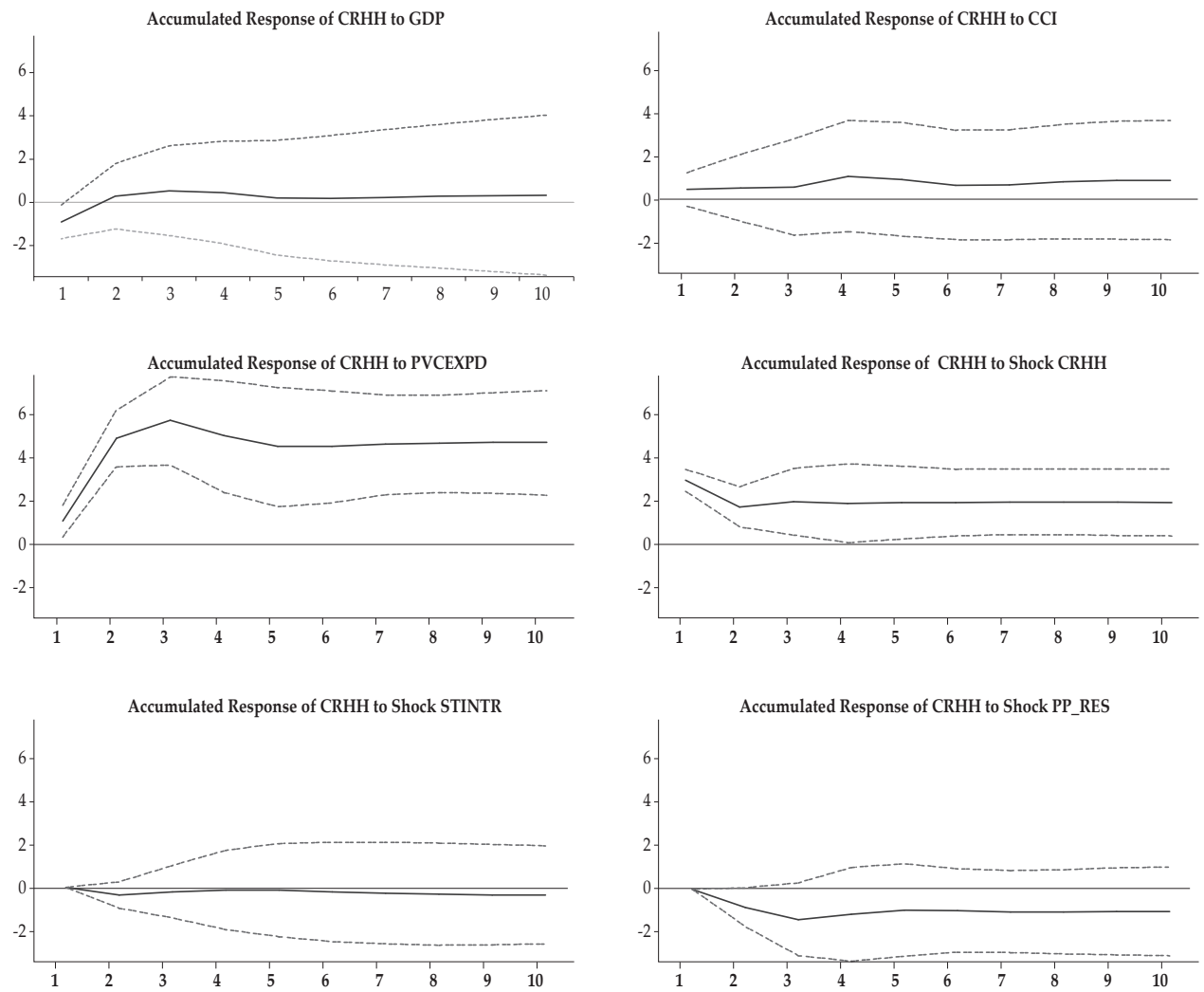
Figure 4.

Impulse Response Functions: Indonesia (Continued)
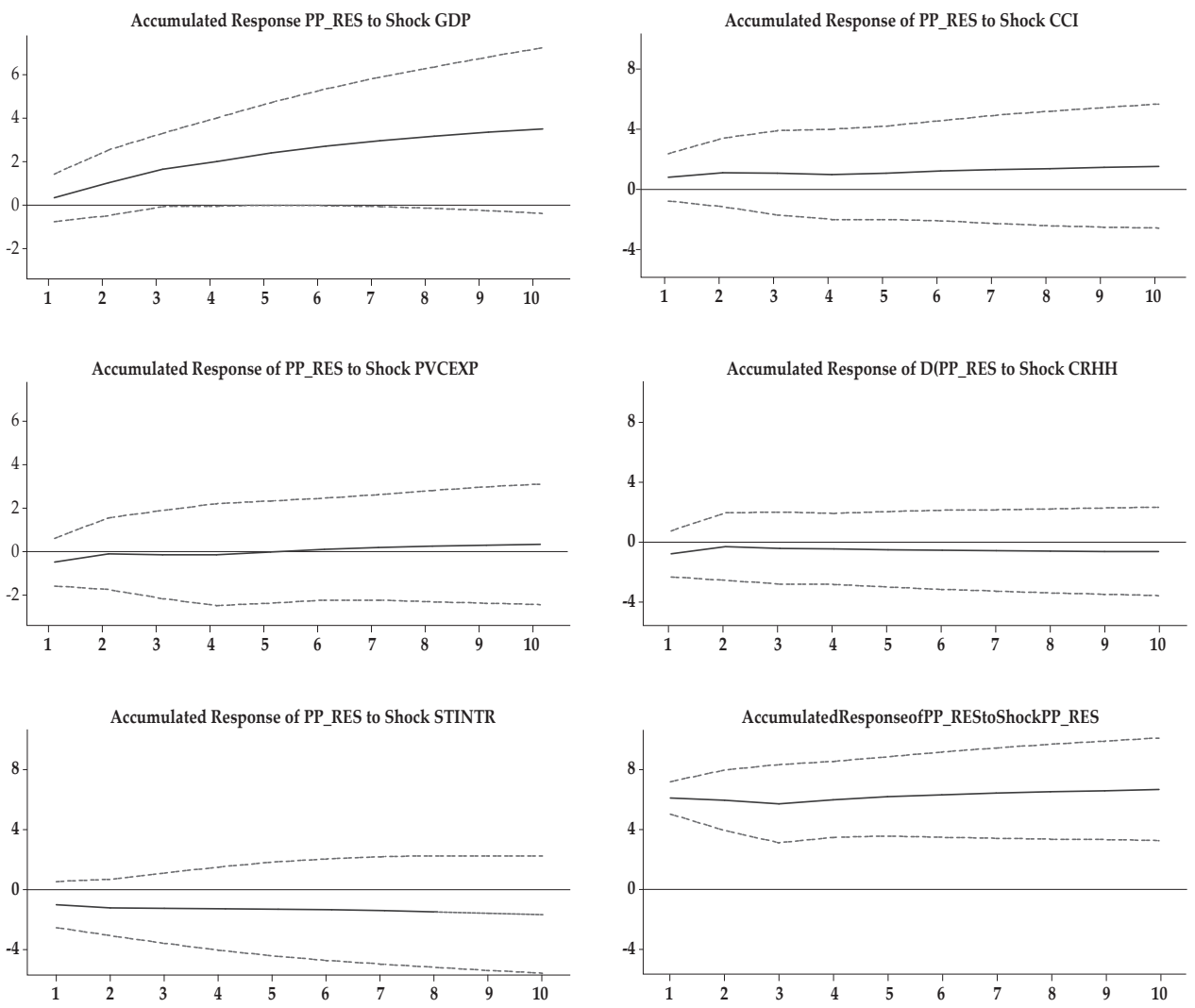

Figure 4 presents the dynamic responses of PP_RES and CRHH to CCI, GDP, PP_RES, CRHH, PVCEXD, and STINTR for Indonesia. The IRFs of the income expectation shocks (measured by the Consumer Confidence Index) on credit to households and residential property prices are plotted in Figures 4 for Indonesia. We consider 20 response periods to account for both short and prolonged effects. The IRF shows that a one-time positive shock to income expectations has a positive impact on property prices in Indonesia, but the effect is not statistically significant. Similarly, a one-time positive shock to income expectations has an equally positive impact on credit to households. This result implies that improved income expectations raise household wealth, leading to a greater demand for household credit and thus positively impacting residential property prices. This is in line with the assumption that institutions consider positive household income expectations an important lending decision criterion for credit expansion. Such expectations allow banks to lower their lending standards, given that the probability of default appears lower during periods of positive economic outlook, as reflected in the CCI. We find no evidence of whether financial institutions consider rising property prices an indicator of credit expansion, at least for Indonesia. We do, however, 
find significant evidence of credit expansion on the onset of both improved GDP and private consumption expenditures. Since the interest rate is considered a fundamental for house prices, the IRFs suggest that residential property prices respond negatively to any contractionary monetary policy shocks. However, this result is not statistically significant at conventional levels.

\section{Figure 5.}

\section{Impulse Response Functions: Brazil}

This figure represents the IRFs derived from the SVAR model (Model 1) for Brazil. The impulse response function traces the effect of a one standard deviation shock to one of the variables on current and future values of all the endogenous variables in the VAR system. Dashed lines represent the intervals of two standard deviations, while the solid lines represent the impulse function.

Accumulated Response to Structural VAR Innovations \pm 2 S.E.
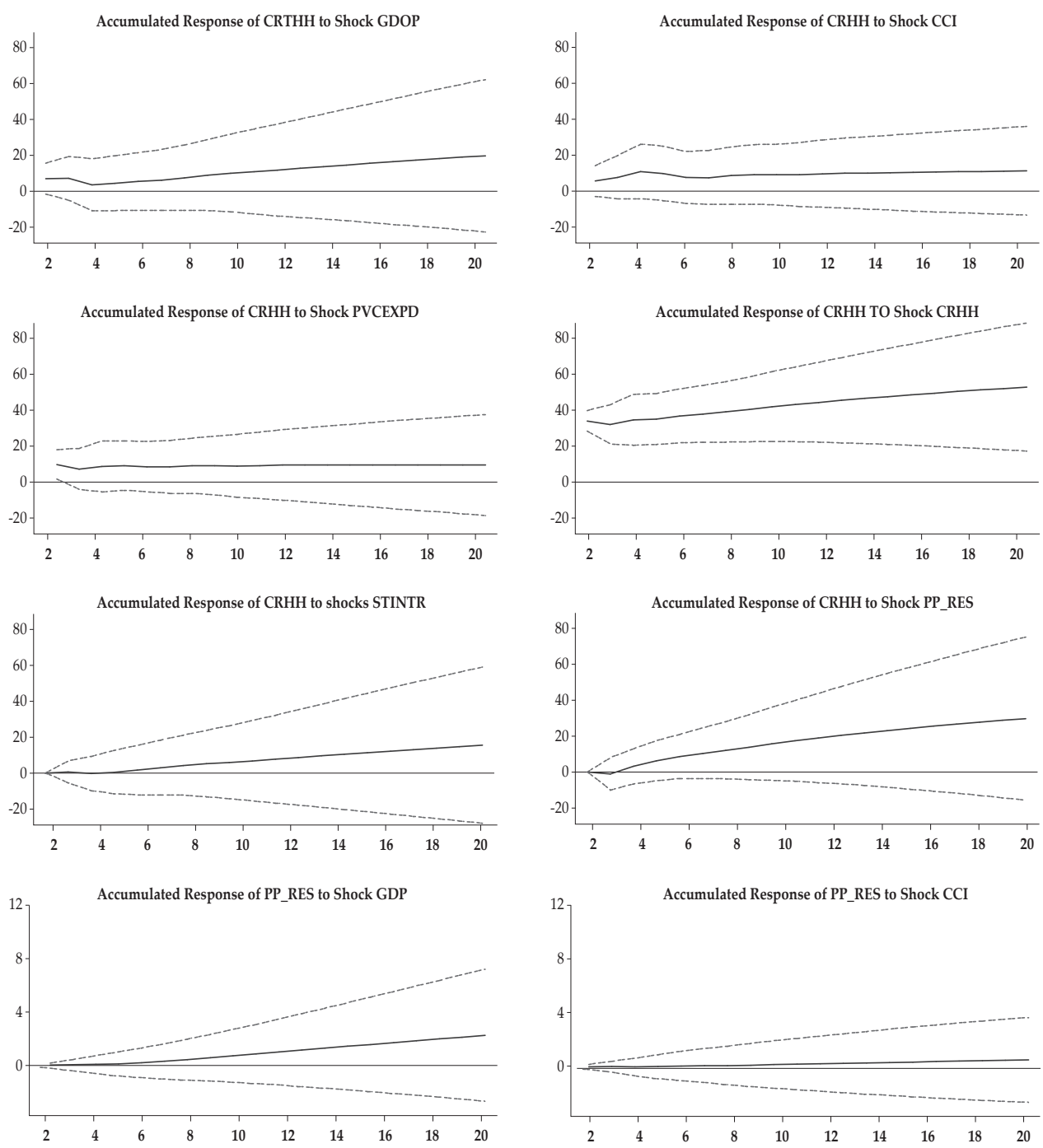
Figure 5.

Impulse Response Functions: Brazil (Continued)
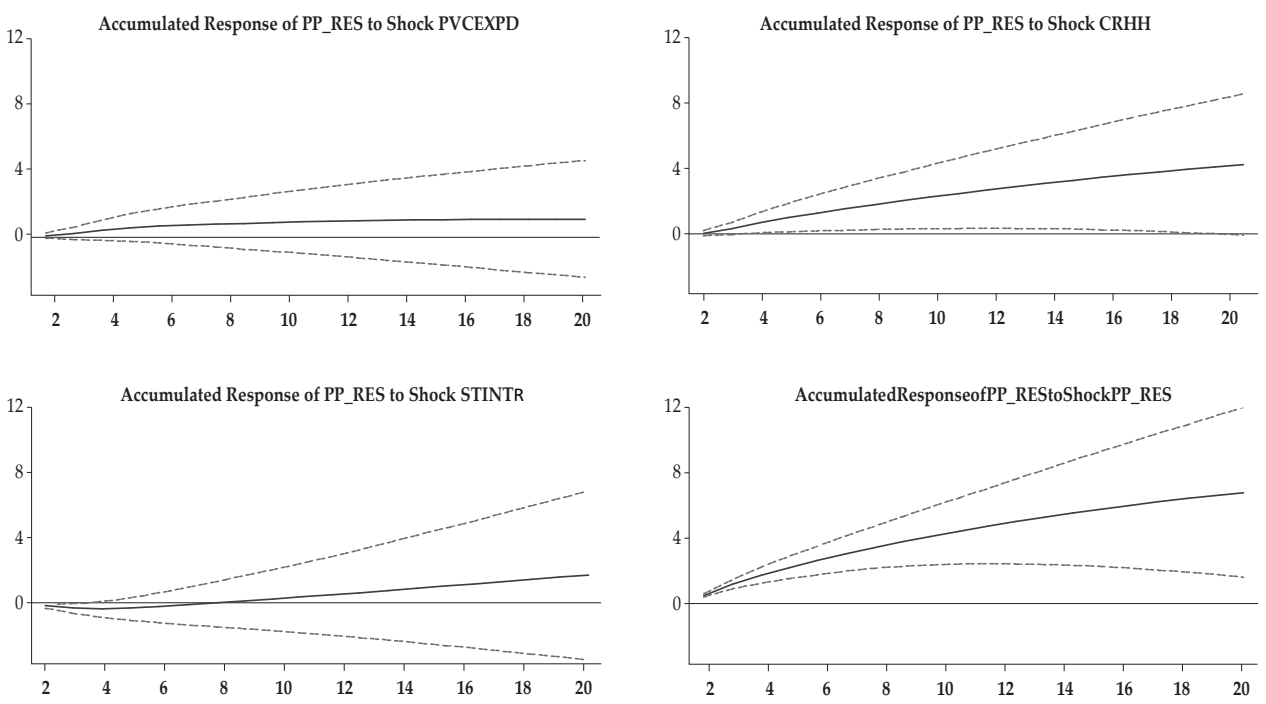

Figure 5 presents the dynamic responses of PP_RES and CRHH to CCI, GDP, PP_RES, CRHH, PVCEXPD, and STINTR for Brazil. It shows that a one-time positive shock to income expectations has a positive but no significant impact on both credit to households and property prices in Brazil. This result implies that rational agents in Brazil do not consider income expectations reflected in the CCI an important indicator for property prices and credit expansion. However, there are feedback and counter feedback effects between property prices and household credit expansion. For example, a one-time positive shock to property prices has a positive and prolonged effect on credit expansion, although it is not statistically significant. Similarly, a one-time positive shock to credit expansion (credit to households) has a positive and significant impact on property prices. However, we find evidence of residential property price increases in response to positive shocks to both improved economic performance and private consumption expenditures.

Further, there is also evidence that a one-time positive shock to residential property prices has a positive and impact on credit expansion. This result is consistent with the credit demand hypothesis, which suggests that financial institutions lower their lending standards as the collateral value of household equity improves due to an increase in property prices. Most importantly, residential property prices rise as overall economic performance improves, which is generally reflected in income expectations.

\section{A5. Variance Decomposition}

To ascertain the importance of both income expectations and household credit when explaining residential property prices for both Indonesia and Brazil, we adopt variance decomposition, as proposed by Kim and Murray (2002). Forecast 
error variance decomposition is a useful tool for examining the interactions between the variables over the impulse response horizon. Table 4 reports the proportion of variations of household credit and residential property as explained by other variables in the SVAR model for Indonesia. The variance decompositions for the second-, eighth-, and 20th-quarter horizons are selected to represent shortterm as well as extended effects. Table 4 reports the proportion of the variations of household credit and residential property prices as explained by other variables in the SVAR model for Indonesia. The findings from the SVAR model further suggest that a one standard deviation shock to income expectations briefly increases credit to households by about $1.5 \%$, lasting for two quarters. The effect remains consistent over a long period. However, household credit is significantly explained by private consumption expenditures, which account for about $54 \%$, followed by GDP, at about $7 \%$, and residential property prices, at about $3.5 \%$. The residential property prices are mostly explained by their own history. Income expectations and household credit explain, on average, about $1.7 \%$ and $2 \%$, respectively, of the variation in residential property prices in Indonesia.

Table 4.

Estimates from Variance Decomposition (Indonesia)

In this table, we present the variance decomposition of credit to household and residential property prices from the 6-variable SVAR model for Indonesia. The responses of both CRHH and PP_RES to a one standard deviation shock to GDP $, C C I, P V C E X P D$ and their own effects for $2^{\text {nd }}$ quarter, $8^{\text {th }}$ quarter and $20^{\text {th }}$ quarter are reported in the table.

\begin{tabular}{lcccccc}
\hline & \multicolumn{7}{c}{ Percentage of Variation due to } \\
\cline { 2 - 7 } & GDP & CCI & PVCEXPD & CRHH & STINTR & PP_RES \\
\hline CRHH & $\%$ & $\%$ & $\%$ & $\%$ & $\%$ & $\%$ \\
2 & 7.628 & 1.476 & 54.571 & 32.422 & 0.515 & 3.384 \\
8 & 7.717 & 1.809 & 54.539 & 31.935 & 0.546 & 3.451 \\
20 & 7.717 & 1.824 & 54.530 & 31.928 & 0.549 & 3.450 \\
PP_RES & $\%$ & $\%$ & $\%$ & $\%$ & $\%$ & $\%$ \\
2 & 2.894 & 1.704 & 1.906 & 2.509 & 2.262 & 89.170 \\
8 & 6.777 & 1.730 & 2.006 & 1.998 & 2.182 & 85.294 \\
20 & 7.299 & 1.820 & 2.047 & 1.984 & 2.269 & 84.577 \\
\hline
\end{tabular}

Table 5.

Estimates from Variance Decomposition (Brazil)

In this table, we present the variance decomposition of credit to household and residential property prices from the 6-variable SVAR model for Brazil. The responses of both CRHH and PP_RES to a one standard deviation shock to $G D P, C C I, P V C E X P D$ and their own effects for $2^{\text {nd }}$ quarter, $8^{\text {th }}$ quarter and $20^{\text {th }}$ quarter reported in the table.

\begin{tabular}{lcccccc}
\hline & \multicolumn{7}{c}{ Percentage of variation due to } \\
\cline { 2 - 7 } & GDP & CCI & PVCEXPD & CRHH & STINTR & PP_RES \\
\hline CRHH & $\%$ & $\%$ & $\%$ & $\%$ & $\%$ & $\%$ \\
2 & 3.417 & 3.434 & 7.396 & 85.630 & 0.023 & 0.092 \\
8 & 4.545 & 4.364 & 7.095 & 80.426 & 0.538 & 3.029 \\
20 & 5.028 & 4.237 & 6.845 & 78.360 & 1.147 & 4.374 \\
PP_RES & $\%$ & $\%$ & $\%$ & $\%$ & $\%$ & $\%$ \\
2 & 0.162 & 1.385 & 2.521 & 7.582 & 4.754 & 83.594 \\
8 & 1.999 & 0.657 & 3.862 & 19.978 & 3.429 & 70.073 \\
20 & 6.334 & 0.696 & 2.639 & 21.865 & 6.763 & 61.680 \\
\hline
\end{tabular}


Table 5 reports the proportion of the variations of household credit and residential property prices as explained by other variables in the SVAR model for Brazil. The findings suggest that a one standard deviation shock to income expectations explains, on average, about $4 \%$ of total variations in credit to household and less than $1 \%$ of residential property price. However, it is worth noting that a one standard deviation shock to household credit leads to an increase in residential property prices of about $7.5 \%$ in the second quarter, followed by increases of $20 \%$ and $22 \%$, respectively, for the $8^{\text {th }}$ and 20 th quarters. This finding suggests that household credit explains a significant portion of the variation in residential property prices in Brazil.

\section{A6. Robustness Test}

Table 6.

\section{Estimates of Long- and Short-run Coefficients from the ARDL model}

In this table, we report results for the long-run relationship between residential property price and other independent variables for which we find evidence of cointegration, as documented in Table 2 . In all the cases, we report HAC standard error \& covariance (Bartlett kernel, Newey-West fixed bandwidth). Given that the data frequency is quarterly, we use 1 lead and 1 lag for the estimation. The variables are PP_RES = Real Property Index, $C R H H=C$ redit to Household sector and other sectors serving household, PVCEXPD = private consumption expenditures in USD; and $C C I=$ is consumer confidence index. All variables are in natural logarithms except STINTR. The standard error is in parenthesis. Finally, ${ }^{* * *},{ }^{* *}$ and ${ }^{*}$ denote statistical significance at the $1 \%, 5 \%$ and $10 \%$ levels, respectively.

\begin{tabular}{|c|c|c|c|}
\hline Variables & $\begin{array}{c}\text { Indonesia } \\
\text { ARDL(1, 0, 0, 0, 0, 0) }\end{array}$ & Variables & $\begin{array}{c}\text { Brazil } \\
\text { ARDL }(4,0,1,0,0,3)\end{array}$ \\
\hline \multirow[t]{2}{*}{ PP_RES(-1) } & $0.864^{* * *}$ & PP_RES(-1) & $1.790^{* * *}$ \\
\hline & $(0.126)$ & & $(0.116)$ \\
\hline \multirow[t]{4}{*}{ GDP } & 0.247 & PP_RES(-2) & $-1.267^{* * *}$ \\
\hline & $(0.233)$ & & $(0.247)$ \\
\hline & & PP_RES(-3) & $0.974^{* * *}$ \\
\hline & & & $(0.239)$ \\
\hline \multirow[t]{2}{*}{$\mathrm{CRHH}$} & -0.152 & PP_RES(-4) & -0.526 \\
\hline & $(0.974)$ & & $(0.112)$ \\
\hline \multirow[t]{4}{*}{ PVCEXPUSD } & $0.0715^{* *}$ & GDP & $0.134 \#$ \\
\hline & $(0.038)$ & & $(0.080)$ \\
\hline & & CRHH(-1) & $-0.247^{* *}$ \\
\hline & & & $(0.099)$ \\
\hline \multirow[t]{4}{*}{$\mathrm{CCI}$} & $4.883^{* *}$ & PVCEXPD & $0.004^{*}$ \\
\hline & $(2.628)$ & & $(0.002)$ \\
\hline & & $C C I$ & 0.143 \\
\hline & & & $(0.150)$ \\
\hline \multirow[t]{8}{*}{ STINTR } & -0.00287 & CCI(-1) & $-0.327^{* *}$ \\
\hline & $(0.0038)$ & & $(0.151)$ \\
\hline & & $\operatorname{STINTR}(-1)$ & 0.246 \\
\hline & & & $(0.171-)$ \\
\hline & & $\operatorname{STINTR}(-2)$ & 0.046 \\
\hline & & & $(0.166)$ \\
\hline & & STINTR(-3) & -0.131 \\
\hline & & & $(0.085)$ \\
\hline
\end{tabular}


Table 6.

Estimates of Long- and Short-run Coefficients from the ARDL model (Continued)

\begin{tabular}{lccc}
\hline Variables & Indonesia & \multirow{2}{*}{ Variables } & Brazil \\
& ARDL(1,0,0,0,0,0) & & ARDL(4, 0, 1, 0, 0, 3) \\
\hline$C$ & $-22.553^{* *}$ & $C$ & $20.810^{* *}$ \\
& $(11.991)$ & & $(10.530)$ \\
Adj-R square & 0.886 & & 0.998 \\
\hline
\end{tabular}

To confirm the validity of long-run estimates reported in Table 3, we use an ARDL model that caters to both the short- and long-run relationships between property price and its determinants. For Indonesia, we have an ARDL model with a distributed lag order of $(1,0,0,0,0,0)$, and the estimates are reported in column 2 of Table 6 . In the short run, only the lagged value of property prices affects current property prices. In the long run, income expectations and private consumption expenditures remain significant, confirming the results based on long-run estimates (DOLS). For Brazil, we have an ARDL model with a distributed lag order of $(4,0,1,0,0$, and 3). For Brazil, in the long run, income expectations are proxied by CCI, GDP, and PVCEXPD, and, in the short run, the lagged value of property prices explains their current value.

\section{CONCLUDING REMARKS}

This study examines the long- and short-run dynamics between property prices, income expectations, and credit to the household sector in Indonesia and Brazil. We use the Consumer Confidence Index to proxy for household income expectations, since it is closely aligned with future economic outlook. A number of interesting findings emerge from our study. We hypothesize that household income expectations, which have been largely ignored in the literature, explain property prices in long run, and the improved optimism in household income expectations affects residential property prices via both the credit and wealth channels.

The key findings show a cointegrating relationship between house prices and other factors considered in the model for both Indonesia and Brazil. The cointegration equations confirm that, in the long run, property prices are positively affected by income expectations, the GDP, and private consumption expenditures, and negatively affected by credit to households. However, in the Brazilian economy, both the GDP and credit to households explain property prices in the long run, but we find no significant impact of income expectations on property prices, compared to the findings for the Indonesian market. These findings are in line with the literature (Green and Hendershott, 1996; Malpezzi, 1999; Capozza et al., 2002; Meen, 2002) that shows a cointegration relationship between house prices and fundamentals factors such as income.

In terms of dynamic interactions between income expectations, household credit, and house prices, we find that property prices respond to income 
expectations via the wealth channel. Shocks in economic performance (GDP) and private consumption expenditures affect household credit in Indonesia. This result is consistent with the finding of Mian and Sufi (2018), who suggest that an optimism shock has led to a rise in house prices, with credit merely following the rise in house prices. In the Brazilian economy, shock in income expectations have no impact on property prices, whereas property prices respond significantly to shocks in the GDP and private consumption expenditures. Household credit responds sharply to rises in property prices. This result is consistent with the finding of Favara and Imbs (2015), who suggest that exogenous expansion in mortgage credit has significant effects on house prices. The implication of the dynamic interactions between income expectations, the household credit, and residential property prices is that variance in residential property prices can be largely explained by lagged value of property prices to themselves, whereas income expectations proxied by the Consumer Confidence Index and the availability of credit to households have an important influence on residential property prices.

\section{REFERENCES}

Adelino, M., Schoar, A., and Severino, F. (2015).House Prices, Collateral, and SelfEmployment. Journal of Financial Economics, 117, 288-306

Adelino, M., Schoar, A., and Severino, F. (2017). Dynamics of Housing Debt in the Recent Boom and Bust. "NBER Macroeconomics of the Financial Crisis in the Propagation of the Great Depression". American Economic Review, 73, 257-76.

Amisano G., Giannini, C. (1997). From VAR Models to Structural VAR Models. In: Topics in Structural VAR Econometrics. Springer, Berlin, Heidelberg.

Asea, P.K., Blomberg, B. (1998). Lending Cycles. Journal of Econometrics, 83, 89-128. Chen, M., Tsai, C., and Chang, C., (2007), House Prices and Household Income: Do They Move apart? Evidence from Taiwan. Habitat International, 31, 243-256.

Bernanke, B. S., Gertler, M., and Gilchrist, S. (1999). The Financial Accelerator in a Quantitative Business Cycle Framework. In: Taylor, J.B., Woodford, M. (Eds.), Handbook of Macroeconomics, 1, 1341-1393.

Capozza, R., Hendershott, Partic H., Mack, C., and Mayer, J. (2002). Determinants of Real House Price Dynamics. NBER Working Paper 9262.

Davis, E.P., Zhu, H. (2011). Bank Lending and Commercial Property Cycles: Some Cross-Country Evidence. Journal of International Money and Finance, 30, 1-21

Davis, E.P., and Zhu, H. (2009). Commercial Property Prices and Bank Performance. The Quarterly Review of Economics and Finance, 49, 1341-1359.

Davis, E.P. (1993). Bank Credit Risk. Bank of England, Working Paper Series 8.

Di Maggio, M., and Kermani, A. (2017). Credit-Induced Boom and Bust. Review of Financial Studies, 30, 3711-58.

Elbourne, A. (2008). The UK Housing Market and the Monetary Policy Transmission Mechanism: An SVAR Approach. Journal of Housing Economics, 17, 65-87.

Favara, G., and Imbs, J. (2015). Credit Supply and the Price of Housing, American Economic Review, 105, 958-92.

Foote, C.L., Gerardi, K.S., and Willen, P.S., (2012). Why Did So Many People Make So Many Ex Post Bad Decisions? The Causes of the Foreclosure Crisis. NBER Working Paper 18082. 
Fuster, A., Laibson, L.I., Mendel, B., (2010). Natural Expectations and Macroeconomic Fluctuations. The Journal of Economic Perspectives, 24, 67-84.

Gallin, J. (2006). The Long-Run Relationship Between House Prices and Income: Evidence from Local Markets. Real Estate Economics, 34, 417-438.

Green, R., and Hendershott, P.H. (1996). Age, Housing Demand, and Real House Prices, Regional Science and Urban Economics, 26, 465-480.

Herring, R.J., Wachter, S.M., (1999). Real Estate Booms and Banking Busts: an International Perspective. The Wharton Financial Institutions Centre. Working Paper 99-27.

Justiniano, A., Primiceri, G., and Tambalotti, A. (2015). Household Leveraging and Deleveraging. Review of Economic Dynamics, 18, 3-20.

Kim, S., and Rubini, N. (2000). Exchange Rate Anomalies in Industrial Countries: A Solution with a Structural VAR Approach. Journal of Macroeconomics, 45, 561586.

Kiyotaki, N., and Moore, J. (1997). Credit Cycles. Journal of Political Economy, 105, 211-248.

Laibson, D., and Mollerstrom, J. (2010). Capital Flows, Consumption Booms and Asset Bubbles: A Behavioural Alternative to the Savings Glut Hypothesis. The Economic Journal, 120, 354-374.

Ludvigson, S.C., (2004). Consumer Confidence and Consumer Spending. Journal of Economic Perspective, 18, 29-50.

Masih, M., and Masih, R. (1996). Energy Consumption, Real Income and Temporal Causality: Results from a Multi-Country Study Based on Cointegration and Error-Correction Modelling Techniques. Energy Economics, 18, 165-183.

Malpezzi, S. (1999). A Simple Error Correction Model of House Prices, Journal of Housing Economics, 8, 27-62.

Meen, G. (2002). The Time-Series Behaviour of House Prices: A Transatlantic Divide. Journal of Housing Economics, 11, 1-23

Mian, A.R., and Sufi, A., (2018). Finance and Business Cycles: The Credit-Driven Household Demand Channel, Journal of Economic Perspectives, 32, 31-58.

Mian, A. R., Sufi, A., and Verner, E. (2017). Household Debt and Business Cycles Worldwide. Quarterly Journal of Economics, 132, 1755-1817.

Narayan, P. K., and Popp, S. (2010). A New Unit Root Test with Two Structural Breaks in Level and Slope at Unknown Time. Journal of Applied Statistics, 37, 1425-1438.

Narayan, P. K., \& Popp, S. (2013). Size and Power Properties of Structural Break Unit Root Tests. Applied Economics, 45, 721-728.

Rajan, R.G. (1994). Why Bank Credit Policies Fluctuate: A Theory and Some Evidence. Quarterly Journal of Economics, 109, 399-441.

Runstler, G., and Vlekke, M. (2018). Business, Housing, and Credit Cycles. Journal of Applied Econometrics, 33, 212-226.

Saikkonen, P. (1991). Asymptotically Efficient Estimation of Cointegrating Regressions. Economic Theory, 7, 1-21.

Stock, J.H., Watson, M.W. (1993). A Simple Estimator of Cointegrating Vectors in Higher Order Integrated Systems, Econometrica, 61, 783-820.

Wang, Z., and Zang, Q. (2014). Fundamental Factors in the Housing Markets of China. Journal of Housing Economics, 25, 53-61. 